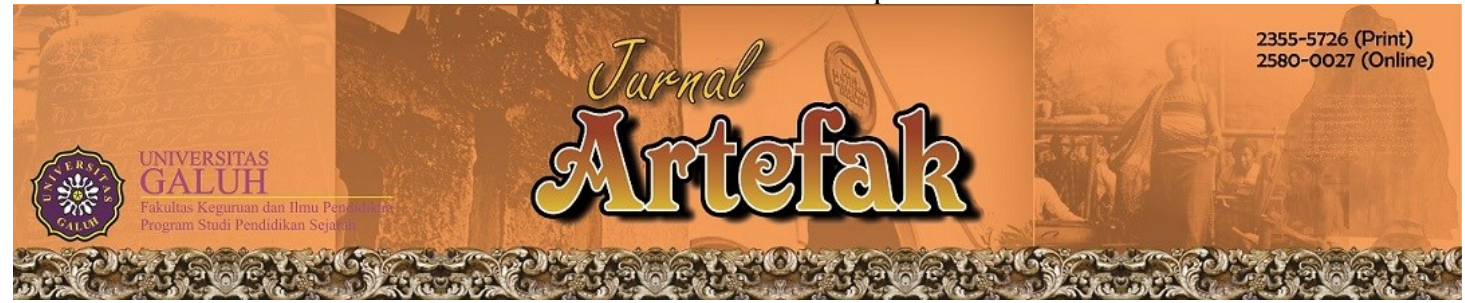

https://jurnal.unigal.ac.id/index.php/artefak/article/view/5170

\title{
PERKEMBANGAN ILMU PENGETAHUAN DI YUNANI \\ DARI ABAD KE-5 SM SAMPAI ABAD KE-3 SM
}

\author{
Wulan Sondarika \\ Universitas Galuh Ciamis, Indonesia \\ E-mail: wulansondarika13@gmail.com \\ Sejarah Artikel: Diterima 1-Maret-2021 Disetujui 15-Maret-2021 Dipublikasikan -April-2021
}

\begin{abstract}
Abstrak
Tujuan penelitian ini adalah untuk mengetahui awal perkembangan ilmu pengetahuan di Yunani dari abad ke-5 SM sampai abad ke-2 SM. Penelitian ini dilakukan dengan menggunakan metode penelitian literatur Pengumpulan data dilakukan dengan cara pencarian sumber buku, jurnal dan hasil penelitian lainnya. Hasil penelitian menunjukkan bahwa Perkembangan Ilmu Pengetahuan Di Yunani Abad ke-5 SM adanya sifat agama yang tidak mengenal ajaran Tuhan yang ditetapkan sebagai akidah. Kemudian keadaan geografis negara tersebut yang mengarah pada perdagangan dan perauntauan sehingga bangsa Yunani sempat bertemu dan bertukar fikiran dengan bangsa-bangsa lain. Dan bentuk negaranya yaitu Republik-Demokrasi sehingga rakyat memerintah dengan tanggung jawabnya sendiri. Selain itu juga terdaat tokoh-tokoh filsuf yang memegang peranan besar atas berkembangnya ilmu pengetahuan di Yunani diantaranya; Thales, Anaximander, Anaximenes, Heraklitus, Parmanides, Pytagoras, Hippocrates, Socrates, Plato, Aristoteles, Empledokles
\end{abstract}

Kata Kunci: Ilmu Pengetahuan, Filsuf, Yunani

\begin{abstract}
The purpose of this study was to determine the early development of science in Greece from the 5 th century $\mathrm{BC}$ to the $2 \mathrm{nd}$ century $\mathrm{BC}$. This research was conducted using literature research methods. Data collection was carried out by searching for sources of books, journals and other research results. The results showed that the development of science in Greece in the 5th century $\mathrm{BC}$ had the nature of religion that did not recognize the teachings of God which was established as a creed. Then the geographical condition of the country led to trade and control so that the Greeks had time to meet and exchange ideas with other nations. And the form of the state is the Republic-Democracy so that the people rule with their own responsibility. In addition, there were philosophers who played a large role in the development of science in Greece, including; Thales, Anaximander, Anaximenes, Heraclitus, Parmanides, Pytagoras, Hippocrates, Socrates, Plato, Aristotle, Empledocles.
\end{abstract}

Keyword: Science, Philosopher, Greece

\section{PENDAHULUAN}

Letak geografis Yunani berada di Laut Tengah tepatnya ujung Tenggara Benua Eropa. Yunani memiliki iklim panas dan sebagian besar tanahnya kering, alamnya berupa jurang-jurang terjal dan gununggunung yang membentang tinggi serta terdapat pantai-pantai yang curam dan terjal disertai dengan batu karang yang tajam. Dengan memiliki iklim panas sudah di pastikan turunnya hujan sangat jarang sekali di negeri Yunani. Awalnya bangsa Yunani merupakan campuran bangsa dari Laut Kaspia, Laut Aegea dan Laut Lonia dengan penduduk asli disana dan pada akhirnya 
membentuk polis-polis atau wilayah. Polis yang terkenal diantaranya yaitu Athena, Sparta, dan Thebe (Aizid, 2018: 398).

Dahulunya wilayah Yunani sangatlah luas tidak seperti Yunani saat ini. Tetapi meliputi lautan Aegea oleh karena itu wilayah Yunani dibagi menjadi empat bagian, diantaranya meliputi;

1. Yunani kepulauan:

a. Laut Aegea; Naxos, Miletus, Melos, Delos, Chio, Lesbos.

b. Laut Lonia; Cephalonia, Zachintus, Luecas.

2. Yunani tengah; Athena, Thebe, Delphi, Corinthia.

3. Yunani utara; Ambracia, parsalus, Larisa, Crannon.

4. Yunani selatan; Mycenae, Messenia, Sparta, Argos, Olympia.

Bersamaan dengan peradaban lainnya seperti Persia, Mesopotamia, India, Cina dan lainnya, Yunani tumbuh dan berkembang menjadi suatu pusat peradaban tertua di Eropa. Yunani menjelma menjadi suatu wilayah yang sangat kuat dan sangat di segani oleh musuhmusuhnya terutama polis Athena dan Sparta. Pada periode klasik sekitar abad ke- 5 SM Yunani di dominasi oleh Athena yang selanjutnya digantikan oleh Sparta pada awal abad ke- 4 SM. Terdapat perbedaan kepribadian antara Athena dengan Sparta. Athena lebih mengutamakan kesustraan atau ilmu pengetahuan dan untuk Sparta lebih mengutakan kemiliteran. Terdapat kebijakan yang berbedan antara di polis Athena dan Sparta. Untuk di Athena semua rakyatnya wajib menuntut ilmu pengetahuan sedangkan di Sparta anak-anak dari usia 13 tahun sudah wajib mengikuti sekolah militer sampai dengan usia 30 tahun.

Solon (638-559 SM) memperkenalkan system demokratis dan system ini dipakai oleh pemerintahan saat itu. Dengan system demokrasi itu, rakyat menjadi memegang kekuasaan. Dalam pelaksanaannya (9) dilakukan oleh Sembilan orang Archon, Archon ini setiap tahunnya berganti. Para anggotanya merupakan mantan dari Archon dan Archon diawasi oleh Aeropagus (Mahkamah Agung) yang (Aizid, 2018: 410).

Di Athena tidak memiliki program militeraisasi dan system pemerintahannya demokrasi yang ketat seperti di Sparta. Karena itu tidak heran jika nantinya Athena ditaklukan oleh Sparta karena rakyatnya tidak dipersiapkan untuk bertarung di medan perang.

Namun terdapat kelebihan yang dimiliki Athena yaitu perkembangan ilmu pengetahuan yang merupakan hasil pemikiran para filosof Athena. Athenapun menjelma sebagai kota pelajar dengan lambing burung hantu yang menandakan kecerdasan dari segala ilmu. Athena menghasilkan para filsuf yang handal yang sapai saat ini hasil dari pemikiran mereka masih sangat bermanfaat seperti Plato, Aristoteles, Thales, Anaximander, Anaximenes, Phytagoras, Heraclitus, Parmenides, Hippocartus, Socrates dan masih banyak lagi. Berkat para filsuf Athena ini Yunani menjelma menjadi peradaban yang maju dalam segala aspek terutama ilmu pengetahuan, karena dengan ilmu pengetahuan maka dunia dapat di genggam dengan cepat. Baik itu dalam ilmu kemiliteran, ilmu ekonomi, ilmu kesehatan, ilmu alam, ilmu bumi dan ilmu-ilmu yang lainnya.

Dari penjelasan di atas peneliti merasa tertarik dan timbul rasa penasaran bagaimana Yunani dapat menjadi sebuah peradaban yang sangat besar terutama dalam bidang ilmu pengetahuan yang sampai saat ini hasil pemikiran para filusuf Yunani masih sangat bermanfaat di seluruh dunia. Untuk itu penelitian ini berpatokan pada masalah bagaimana awal perkembangan ilmu pengetahuan di Yunani abad ke-5 SM?, serta Siapa saja tokoh-tokoh filsuf yang memegang peranan besar atas berkembangnya ilmu pengetahuan di Yunani. 


\section{METODE PENELITIAN}

Dari judul di atas, untuk itu penelitian ini menggunakan kajian pustaka atau metode studi litelatur. Metode studi litelatur adalah suatu kegiatan penelitiann yang sumbernya atau pengumpulan datanya berupa pustaka atau buku, membaca dan mencatat, serta mengelola bahan penelitian (Zed dalam Kartiningrum, 2018).

Studi kepustakaan itu dilaksakan oleh seorang peneliti dengan tujuan utama yaitu mencari dasar pondasi untuk memperoleh dan membangun landasan teori, kerangka berfikir, dan menentukan dugaan sementara atau disebut juga dengan hipotesis penelitian. Adapun langkah dalam metode studi pustaka ini yaitu diantaranya; penentuan topik penelitian, dan ditetapkannya rumusan masalah kemudian mencari sumber primer baik itu berupa buku, journal, artikel ilmiah, litelatur review yang berisikan tentang konsep yang diteliti.

\section{HASIL PENELITIAN DAN PEMBAHASAN}

\section{Awal Perkembangan Ilmu Pengetahuan Di Yunani Abad 5 SM}

Lahirnya pemikiran intelktual dari bangsa Yunani disebabkan oleh faktor-faktor berikut:

1. Faktor geografis, alam Yunani berupa gunung-gunung yang tidak subur dan tandus. Dari hal tersebut masyarakat Yunani merasa tertantang dan memutar otak untuk lebih bisa kreatif dalam menjalani hidup.

2. Orang-orang Yunani banyak membangun diplomasi dengan bangsa-bangsa lain, seperti Babilonia, Mesir, dan yang lainnya, sehingga dari hasil diplomasi tersebt terjadilah suatu tukar-menukar pengetahuan.

3. Masyarakat Yunani memiliki hak otonom kemerdekaan dan kemakmuran dibidang ekonomi. Sehingga mereka bisa lebih berkreasi untuk mengembangkan perekonomian keluarga mereka.

4. Bangsa Yunani sangat menghargai logika atau akal dan cara berfikir yang rasional setiap manusia.

5. Bangsa Yunani selalu terlibat aktif dalam urusan ekonomi, politik dan social. Hal itulah yang membuat mereka pintar dalam berusaha untuk mencari pemecahan dalam setiap masalah yang muncul (Aizid, 2018: 411).

Selain faktor di atas juga terdapat faktor lain seperti di Athena adanya kondisi yang memberi kebebasan dalam berfikir dan mengeluarkan pendapat secara kritis. Selainitu ada juga sejumlah factor sehingga berlangsungnya suatu kebebasan berfikir dan mengeluarkan pendapat saat itu adalah:

1. Keadaan alam geografis bangsa Yunani tersebut yang mengarah pada perdagangan dan perauntauan sehingga Yunani sering bertemu dan bertukar fikiran atau sharing dengan bangsa-bangsa lain diluar sana sehingga terbukalah pemikran mereka.

2. Adanya sifat agama yang tidak mengenal ajaran Tuhan yang ditetapkan sebagai akidah (kanon).

3. Keadaan geografis negara tersebut yang mengarah pada perdagangan dan perauntauan sehingga bangsa Yunani sempat bertemu dan bertukar fikiran dengan bangsa-bangsa lain.

4. Keadaan bangsa Yunani sebagai suatu kesatuan (Ridwan, 2010: 14).

5. Bentuk negaranya yaitu RepublikDemokrasi sehingga rakyat memerintah dengan tanggung jawabnya sendiri.

Melihat uraian di atas, maka berfikir dengan filosofis dan lahirnya pemikiran secara kritis sudah ada sejak zaman Yunani Kuno, yaitu di Milite, salah satu kota di Yunani. Ketika yang berkembang adalah filsafat Barat. Kelahiran pemikiran filsafat ini berawal dari abad ke-6 SM dengan runtuhnya mite dan 
cerita-cerita atau mitologi yang selama ini hal tersebut menjadi suatu pembenaran bagi masyarakat Yunani terhadap setiap gejala alam yang terjadi pada saat itu. Melalui mite itu manusia mencari berbagai penjelasan ihwal asal muasal terjadinya alam semesta dan seluruh kejadian yang terjadi di dalamnya. Pada saat itu ada dua mite yang berkembang yaitu mite kosmogonis dan mite kosmologis.

Sebenarnya mitologi Yunani dapat memberikan semua jawaban dari pertanyaan manusia Yunani pada saat itu mengenai alam semesta, namun sayangnya, seluruh jawaban tersebut disampaikan dalam mite yang lolos dari control akal (rasio). Cara berfikir seperti ini terjadi sampai abad ke-6 SM, sebelum manusia mencari jawaban-jawaban yang rasional mengenai asal-muasak dan mengenai kejadian alam semesta.

Di awal kelahirannya, ciri atau penanda penting dalam tradisi filsafat Yunani Kuno adalah adanya suatu perhatian yang amat besar terutama pada pengamatan gejala kosmik dan fisik. Ini merupakan usaha dalam menemukan penjelasan ihwal asal mula dari terjadinya semua gejala. Bagi Thales (640-550 SM) air merupaka asal mula dari segala sesuatu. Pandangan ini di dukung oleh kenyataan obyektif, betapa air dapat meresapi seluruh benda-benda di alam semesta ini. Dan operion, segala sesuatu yang tidak terbatas, merupakan pusat keyakinan tentang asal mula yang muncul dalam pemikiran Anaximander (611-545 SM). Sedangkan dalam pandangan Anaximenes (588-524 SM) asal muasal segala sesuatu itu udara, sesuai dengan kenyataan bahwa udara merupakan unsur yang sangat penting di dalam suatu kehidupan (Ridwan, 2010: 15).

Zamannya Yunani kuno bisa juga disebut dengan periode filsafat alam. Sebab, pada periode ini banyak melahirkan ahli pikir alam. Arah dan penelitian mereka lebih banyak tertuju pada suatu objek yang ada di sekitar mereka. Para filosof selalu mencari permasalahan berupa pertanyaan-pertanyaan mengenai gelaja alam yang bersifat filsafat (berdasarkan akal pikir), dan tidak berdasarkan pada pemikiran secara mitos. Para filosof itu mencari asas yang pertama dari alam semesta yang sifatnya mutlak (Aizid, 2018:420).

Diskusi-diskusi filsafat periode Yunani kuno menjadi semakin semarak dengan lahirnya dua filosof, yaitu Parmenides (540475 SM) dan Herakleitos (540-475 SM). Pemikiran dari para filusuf ini yaitu apakah realitas itu berubah atau sesuatu yang menetap? Bukan lagi soal apakah asal-usul dan kejadian alam semesta. Menguti ungkapan Herakleitos yang terkenal yaitu "panta rhei khai uden menei" (semua mengalir dan tidak ada sesuatu pun yang tinggal tetap). Tapi Permenides berpandangan lain, ia menjelaskan dengan tegas bahwa realita tidak berubah karena sifatnya tetap. Arti penting tentang gagasan Permenides ialah gagasan tentang "ada". Pemenides merupakan filosof yang pertama kalinya yang mempraktikkan cabang ilmu filsafat yang di kemudian hari disebut dengan "metafisika". Pernyataannya metafisika yang sering di jelaskan ialah "yang ada itu ada, dan yang tidak ada itu tidak ada". Dalam sejarah filsafat Yunani, Herakleitos dan Parmenides merupakan awal mula debat metafisika yaitu tentang "pluralism" dan "monism" pada bidang epitimologi antara "empirisme" da "rasionalisme". Herakleitos mewakili pluralism dan empirisme, dan Parmenides idalah perwakilan dari monisme dan rasionalisme (Ridwan, 2010: 15).

Maka dapat disimpulkan bahwa awal perkembangan ilmu pengetahuan di Yunani abad 5 SM diawali dengan diskusi-diskusi kecil antar seorang guru dengan murid yang mengasulkan pemikiran rasional. Pemikiranpemikiran tersebut dikembangkan menjadi sebuah ilmu yang dapat di buktikan kebenarannya sehingga kebenaran tersebut dapat diterima oleh umat manusia hingga saat ini. 
Tokoh-tokoh filsuf yang memegang peranan besar atas berkembangnya ilmu pengetahuan di Yunani

Di polis Athena banyak menghasilkan para filsuf yang pemikirannya sangat berpengaruh pada kehidupan manusia dari zaman dulu hingga sekarang. Para filsuf ini antara lain sebagai berikut:

1. Thales (624-546 SM), ia merupakan ahli matematika dan astronomi. Thales dengan ilmu perhitungannya tentang terjadinya gerhana, dengan menghitung ketinggian piramida dengan menghitung bayangannya. Selain itu juga Thales berpendapat bahwa bumi itu berasal dari air (Djaja, 2012: 14).

Selain ahli matematika dan astonomi, Thales juga seorang politikus, ahli geometri, dan filsafat. Sebagai "Bapak Filsafat/ The Father of Philosophy" Thales merupakan ahli filsuf atau ilmuan yang menciptakan sejarah filsafat Barat pada abad ke-6 SM. Sebelum Thales cara berfikir orang Yunani sangat mengutamakan berfikir mitologis atau legenda dalam setiap berbeda dengan Thales, ia merupkan ahi filsafat pertama di Eropa yang mencoba menjelaskan bahwa dunia dan gejala isinya tidak bersandar pada mitos, melainkan pada rasio dan logika manusia. Selain itu, dalam bidang matematika Thales merupakan pelopor pertama geometri abstrak yang di dasarkan pada cara mengukur banjir. Implementasinya dilakukan dengan cara membuktikan ilmu-ilmu geometri, salah satunya yaitu menyatakan bahwa kedua sudut alas dari satu segitiga sama kaki adalah sama besarnya. Jasanya yang lain dan ini merupakan jasa yang besar adalah memperkirakan gerhana matahari pada tahun 585 SM. Sebagai ilmuwan ia juga mempelajari ilmu fisika magnetism dan listrik. Dan juga Thales mengembangkan ilmu matematika dan astronomi dengan menjelaskan pendapatnya bahwa bulan bersinar karena memantulkan cahaya matahari, menghitung terjadinya gerhana matahari, bahwa kedua sudut alas dari suatu segi tiga sama kaki sama besarnya. Dengan penjelasan di atas dapat disimpulkan bahwa Thales ialah seorang ahli matematika pertama dan sebagai The Father of Deducative Reasoning (bapak penalaran dedukatif) (Aizi, 2018:436).

2. Anaximander/ Anaximandros (610-546 SM), murid Thales dan ia seorang ahli filsuf dari madzhab Miletos. Anaximandros adalah ilmuan pertama yang tidak menggunakan tulisan berhuruf prosa. Ia juga merupakan filsuf yang berjasa dalam bidang astronomi dan geografi. Selain itu juga Anaximandros adalah orang pertama yang menciptakan suatu traktat dalam kesusastraan Yunani. Jadi ia merupakan orang pertama yang menciptakan peta bumi. Anaximandros berpendapat mengenai arche (asas alam semesta) ia menjelaskan bahwa hal itu merupakan sesuatu yang tidak dapat diamati indra, yaitu apeiron (to apeiron = yang tak terbatas) tetapi tidak menunjuk pada salah satu unsur yang dapat di amati oleh indra. Akan tetapi, sebagai suatu unsur yang tak terbatas, abad sifatnya, ada pada segala-galanya, tidak berubah-ubah, sesuatu yang paling dalam. Alasannya apabila ia menunjuk pada salah satu unsur arche, maka hal tersebut akan memiliki karakter yang dapat bergerak sesuai dengan sifatnya, sehingga tidak akan ada tempat bagi unsur yang berlawanan (Aizid, 2018: 445).

Pendapat yang lain ia menyatakan bahwa bumi di ibaratkan seperti silinder yang ukurannya lebih kecil dari matahari. Dan juga pendapatnya yang lain bahwa segala sesuatu yang ada di bumi ini berasal dari satu bahan tunggal tetapi bukan air (Djaja, 2012: 15).

3. Anaximenes (545-528 SM), merupakan seorang filsuf yang dari polis Miletos, sama dengan Thales dan Anaximandros. 
Anaximenes usianya lebih muda dari Anaximandros, ia hidup sezaman dengan kedua filsuf tersebut, ia sering mempelajari tentang filsafat alam, yaitu sesuatu yang menjadi prinsip dasar (arche) segala sesuatu (Aizid, 2018: 447).

Anaximenes juga mengemukakan pendapatnya bahwa bahan alam terbentuk dari udara (Djaja, 2012: 14).

Hal ini juga dikemukakan oleh Nawawi (2017 :148) bahwa jiwa merupakan udara yang bisa berfungsi dengan nafas. Udara menghasilkan semua benda yang ada di alam semesta dikarenakan suatu proses "pemadatan dan pengenceran". Apabila udara bertambah kepadatannya maka muncullah berturutturut angin, air tanah dan akhirnya batu. Akan tetapi apabila udara menjadi lebih encer, yang muncul adalah api.

4. Pythagoras dilahirkan di daerah Samos (polis Ioni), selanjutnya berpindah ke Kroton (Italia Selatan). Pythagoras merupakan soeranng ilmuan yang ahli dalam bidang matematika. ia dikenal sebagai Bapak Bilangan, dan salah satu ilmu yang masih digunakan yaitu mengenai teorema Pythagoras, ia berpendapat bahwa kuadrat hipotenusa dari suatu segitiga siku-siku adalah sama dengan jumlah kuadrat dari kaki-kakinya atau sisi-sisi siku-sikunya. Meskipun teori ini telah banyak diketahui oleh manusia sebelum Pythagoras, namun teorema ini dinobatkan kepada Pythagoras karena ia merupakan manusia pertama yang membuktikan pengamatan ini secara matematis. Pythagoras juga mendirikan lembaga pendidikan yang disebut Pythagoras Society (Karim, 2014: 278).

Julukan Pytagoras "bapak bilangan" atau "bapak matematika" pada akhir abad ke-6 SM ia menyumbang sesuatu yang penting terhadap ilmu filsafat dan ajaran keagamaan. Satu diantara peninggalan Pytagoras yang sangat dikenal ialah teorema. Teorema Pytagoras menjelaskan bahwa kuadrat hepotenusa dari suatu segitiga siku-siku adalah sama dengan jumlah kuadrat dari kaki-kakinya (sisi siku-sikunya) (Aizid, 2018: 430).

5. Heraclitus (535-475 SM), berasal Ephesus (Turki). Ia meyakini bahwa arche (api merupakan asas yang pertama dari alam semesta) Api dilambangkan sebagaiarti dari perubahan dan kesatuan. Api memiliki sifat dapat menghancurkan semua yang ada, dan berubah menjadi abu atau asap. Walaupun suatu objek itu dibakar dan pada akhirnya menjadi abu atau asap, tetapi api tetap ada. Karena pada prnsipnya semua tercipta dari api dan akan kembali ke api (Aizid, 2018: 443).

Djaja (2012: 15) juga berpendapat bahwa Heraclitus seorang filusuf yang mengembangkan pemikiran tentang logika.

Ilmu filsafat Heraclitus tersohor dengan filsafat "menjadi" ia menjelaskan bahwa segala sesuatu sedang menjadi, dan selalu berubah. Kata-katanya yang terkenal adalah panta rhei kai uden menci, artinya segala sesuatunya mengalir bagaikan arus sungai dan tidak satu orangpun dapat masuk ke sungai yang sama dua kali. Alasannya karena air sungai yang pertama telah mengalir, berganti dengan air yang berada di belakangnya. Demikian juga segala yang ada, tidak ada yang tetap, semuanya akan berubah. Akhirnya, dikatakan bahwa hakikat segala sesuatu adalah menjadi, maka filsafatnya dikatakan filsafat menjadi (Aizid, 2018: 443).

6. Parmanides (540-475 SM), berasal dari kota Elea di Italia selatan. Ia merupakan tokoh relativesme yang penting. Ia dikenal sebagai tokoh logikawan pertama dalam sejarah filsafat, bahkan disebut sebagai filsuf pertama modern (Aizid, 2018: 440).

Djaja (2012: 15) menjelaskan bahwa Parmanides mengemukakan pentingknya logika dalam mengembangkan ilmu pengetahuan. 
Salah satu logika dari pemikiran Parmanides yaitu Bersatu ialah bentuk dari realitas, sesuatu itu tidak bergerak dan tidak berubah. Ia mengungkapkan bahwa yang ada itu ada. Inilah kenyataan dan kebenaran. Ukuran kebenaran adalah akal manusia (Aizid, 2018: 441).

7. Hippocrates (469-377 SM), seorang filsuf yang ahli dalam bidang kedokteran (Djaja, 2012: 15).

Aizid (2018: 431) juga menjelaskan bahwa Hipokrates disebut juga "bapak Ilmu Kedokteran Modern" ia adalah tokoh kedokteran dan filsafat Yunani yang dianggap dengan mengeluarkan diagnosis secara sistematis pada pasien, mempelajari penyakit, dan melakukan pengobatan dengan metode empiris dan rasional. Dengan demikian, Hipokrateslah yang telah membedakan antara penyakit yang bukan disebabkan oleh kutukan/ hukuman dari Dewa atau kekuatan lainnya. Akan tetapi, didalam proses pengobatannya ia selalu memperhatikan aspek agama. Hipocrates pernah mengungkapkan "ilmu kedokteran adalah ilmu yang mulia oleh karena itu hanya orang-orang yang sanggup menjunjung kehormatan diri dan profesilah yang layak menjadi dokter".

8. Socrates (469-399 SM), di zaman Yunani kuno, Socrates merupakan seorang yang sangat terpelajar dan intelektual yang tinggi sehingga ia dikerkenal berkat ilmu pengetahuan dan kebijaksanaannya yang sangat tinggi. Mengenai biografi Socrates, tidak banyak orang mengetahuinya. Tetapi sebagian sumber menjelaskan keterangan tentang dirinya dapat diperoleh dari tulisan Aristhopanes, Plato, Xenophon, dan Aristoteles. Muridmuridnyalah yang benyak menerangkan tentang Socrates, karena ia tidak banyak meninggalkan tulisan. Orang yang paling banyak menulis tentang Socrates adalah Plato, yang berupa dialog-dialog (Aizid, 2018: 421).
Ajarannya tentang ilmu filsafat mengenai etika atau kesusilaan bahkan logika banyak dijelaskan oleh Sokrates. Ia mengajarkan agar manusia dapat membedakan hal-hal yang benar atau salah, baik atau buruk, dan adil atau tidak adil. Ajarannya ditujukan pada anak muda yang diajaknya berdiskusi (Djaja, 2012: 15).

Socrates mengemukakan pendapatnya bahwa pengetahuan dan kehidupan adalah satu dan tidak dapat dipisahkan antara satu dengan yang lainnya. Untuk itu, pengujian diri sendiri merupakan dasar dari penelitian dan pembahasannya. Bagi Socrates pengetahuan yang sangat berharga adalah pengetahuan tentang diri sendiri. Semboyan yang paling disukainya adalah tulisan yang tertera di Kuil Delphi yaitu "Kenalilah dirimu sendiri" (Aizid, 2018: 422).

Di akhir hidupnya ia dihukum mati dengan cara dipaksa untuk minum racun karena tuduhan telah merombak dasardasar etika masyarakat Yunani Kuno serta tidak percaya kepada dewa-dewa yang telah disembah dari zaman nenek moyang (Djaja, 2012: 15).

Tahun 399 SM Socrates dituduh merusak mental pemuda Yunani dan menolak Tuhan-Tuhan. Walaupun demikian, Bapak Eksistensialisme Modren yaitu Kierkegaard sangat mengagumi Socrates bahkan filsafat Socrates dijadikan model filsafatnya. Karena socrates secara konstan menentang orang-orang sofis pada zaman itu (Fahriansyah, 2015: 25).

9. Plato (427-347 SM) dia dilahirkan di Athena dan pada usia 20 tahun ia murid dari Socrates dan merupakan satu-satunya yang menggunakan terminologi filsafat (Ridwan, 2010: 19).

Idea merupakan ajaran filsafatnya. Dan buku yang telah ditulisnya berjudul Republica. Dalam buku tersebut 
dijelaskan tentang derajat wanita yang harus diangkat dan kebahagiaan hidup yang dapat dicapai bila manusia bekerja dengan wataknya. Selain itu juga Plato mendirikan pusat Pendidikan yang diberi nama Academus/ Akademi di Kawasan hutan kecil Akademe. (Djaja, 2012: 16).

Selain berkosep mengenai idea Plato juga berkonsep mengenai Tuhan. Bahwa Tuhan bagi seorang Plato dipahami sebagai jiwa alam semesta artinya adalah ajaran Tuhan sebagai sumber utama dari semua gerakan yang terjadi dalam alam semesta. Plato menyadari tidak ada yang bisa menggerakan alam semesta beserta isinya selain Tuhan. Bulan, matahari dan bintang-bintang, mengatur gerakan semua benda langit dalam orbitnya masingmasing (Weisman, 12: 2015).

Plato mempelajari filsafat dari Socrates, Pythagoras, Heracleitos, dan Elia. Ia berpendapat bahwa manusia berada di dalam dua dunia, yaitu dunia pengalaman yang bersifat tidak tetap, bermacam-macam, dan berubah. Sedangkan yang kedua adalah dunia ide merupakan dunia yang sesungguhnya, yaitu dunia realitas. Selama 40 tahun lamanya Plato menghabiskan usianya untuk mengaar di Akademi hingga ia wafat di usia 81 tahun (Aizid, 2018: 424).

Selain tangtang idea dan keTuhanan Plato juga berpendapat bahwa ada tiga level hakikat manusia, aktifitas nafsu, pengindraan, kehendak, intelegensi atau akal (Roswantoro, 2015:126).

10. Aristoteles (384-322 SM), merupakan murid Plato, ia ahli dalam bidang ilmu biologi dan ilmu ketatanegaraan. Hasil karyanya yang terkenal adalah Klasifikasi Flora dan Fauna yang dilakukan di Kepulauan Aegea Yunani. Ada lagi dibidang Ketatanegaraan, Aristoteles mengemukakan bahwa sistem pemerintahan yang baik yaitu mengutamakan kebahagiaan rakyatnya, bukan malah sebaliknya, rakyat menderita karena penguasa yang serakah. Aristoteles juga berjasa atas Pendidikan di Yunani karen ia merupakan pendiri dari pusat Pendidikan yang bernama Peripatetis. Salah seorang muridnya ialah Alexander Agung, yang merupakan Raja Makedonia (Djaja, 2012: 16).

Begitu juga dengan Aizid (2018: 426) menjelaskan bahwa Aristoteles dijuluki dengan bapak metode Ilmiah Modern. Ia lahir di kalangan keluarga terpelajar. Ayahnya merupakan seorang dokter pribadi raja Macedonia, Amyntas. Karena Aristoteles hidup dalam lingkungan istana, ia mewarisi keahliannya dalam pengetahuan empiris dari ayahnya. Selama 20 tahun ia belajar di Athena dan menggali ilmu di Akademia Plato pada usia 17 tahun dan akhirnya ia menjadi pengajar disana. Kita dapat enemukan karya Aristoteles yang berjumlah delapan pokok bahasan, yakni filsafat alam, psikologi, logika, biologi, dan matematika yang oleh Aristoteles ilmu-ilmu tersebut dinamakan filsafat pertama atau theologia-etika, ekonomi dan politik, putika dan serta retorika.

Sekitar tahun 342 SM, Aristoteles mendapatka mandat yang amat berat tetapi mulia oleh raja Philiphus untuk mendidik putranya yaitu Iskandar Dzulkarnaen (Alexander Agung) yang kelak suatu hari nanti mampu menciptakan Imperium baru (kerajaan dunia). Ia seorang filosof Yunani yang sangat mengutamakan nalar dan moderasi (pengendalian diri) sebagai patokan untuk menjalankan hidupnya. Dikenal hingga abad pertengahan oleh para intelektual dengan sebutan "The Philosopher" (sang filosof) (Ridwan: 2010: 31).

Menurut Soedarmo dkk (2012: 4) Catatan yang ditulis oleh Aristoteles, lebih kurang pada abad ke-4 SM, yang salah satu bagiannya menyatakan "Raja yang memerintah di pulau Kreta dan pulaupulau sekitarnya bernama Minos". 
11. Empedokles (495-435 SM), merupakan seorang ahli filsuf dari Madzhab Pluralisme. Ada juga Anaxagoras selain Empedokles. Apabila para filsuf Miletos lainnya mengajarkan terdapatnya satu prinsip dasar yang dapat mempersatukan alam semesta, namun sebaliknya dengan Empledokles. Menurutnya, bahwa prinsip dasar itu berjumlah empat, dan tidak tunggal. Ia dikenal sebagai seorang dokter, politikus, pidato, penyair.

Empedekles selalu menulis karyanya dalam bentuk puisi. Puisinya yang pertama diberi judul Periha Alam (On Nature), dan yang kedua diberi judul Penyucian-penyucian (Purifications). Masing-masing judul tersebut memiliki 5000 ayat, namun yang masih ada hingga kini tinggal 350 ayat dari karya pertama, dan 100 dari karya kedua. Para ahli tidak sepakat mengenai karangan yang lebih dahulu ditulis (Aizid, 2018: 447).

Dari uraian di atas dapat kita ketahui para filsuf-filsuf Yunani yang telah banyak menciptakan karya berupa ilmu pengetahuan diantaranya adalah ilmu tetang hokum, ilmu pemerintahan, ilmu alam, ilmu biologi, ilmu bumi, ilmu social, ilmu seni atau budaya, ilmu kedokteran yang sampai saat ini ilmu-ilmu tersebut masih di gunakan oleh umat manusia.

\section{KESIMPULAN}

Perkembangan Ilmu Pengetahuan Di Yunani Abad 5 SM adanya sifat agama yang tidak mengenal ajaran Tuhan yang ditetapkan sebagai akidah. Kemudian keadaan geografis negara tersebut yang mengarah pada perdagangan dan perauntauan sehingga bangsa Yunani sempat bertemu dan bertukar fikiran dengan bangsa-bangsa lain. Dan bentuk negaranya yaitu Republik-Demokrasi sehingga rakyat memerintah dengan tanggung jawabnya sendiri.

Tokoh-tokoh filsuf yang memegang peranan besar atas berkembangnya ilmu pengetahuan di Yunani diantaranya; Thales, Anaximander, Anaximenes, Heraklitus, Parmanides, Pytagoras, Hippocrates, Socrates, Plato, Aristoteles, Empledokles.

\section{DAFTAR PUSTAKA}

Aizid, R. 2018. Sejarah Terlengkap Peradaban Dunia. Depok: PT Huta Parhapuran.

Djaja, W. 2012. Sejarah Eropa dari Eropa kuno hingga Eropa modern Ombak. Yogyakarta.

Fahriansyah. 2014. Antisofisme Socrates. $A l^{\prime}$ Ulum (e-Journal), Vol 61(3), 24-29

Karim, A. 2014. Sejarah Perkembangan Ilmu Pengetahuan. Fikrah: Jurnal Ilmu Aqidah dan Studi Keagamaan 2(2), 273-289

Kartiningrum. 2018. Metode Penelitian. Yogyakarta.

Nawawi, N. 2017. Tokoh Filsuf dan Era Keemasan Filsafat. Makasar: Pusaka Almaida.

Ridwan, J dkk. 2010. Tokoh-Tokoh Ahli Fikir Negara dan Hukum. Nuansa. Bandung.

Roswantoro, A. 2015. Filsafat Sosial Politik Plato dan Aristoteles. Refleksi: Jurnal Filsafat dan Pemikiran Islam, 15(2), 123-138

Soedarmo, U.R, dkk. 2012. Eropa: dari peradaban pulau Kreta sampai dengan munculnya gerakan reformasi Gereja, Ciamis: Unigal Press.

Weismann, I. Th.J. 2015. Filsafat Ketuhanan Menurut Plato. Jurnal Jaffray 3(1), 1118. 
Jurnal Artefak:

Vol.8 No.1 April 2021 [86-96]

Halaman | 96 